\title{
Effects of high-molecular-weight dissolved organic matter on nitrogen dynamics in the Mississippi River plume
}

\author{
Wayne S. Gardner ${ }^{1, *}$, Ronald Benner ${ }^{2}$, Rainer M. W. Amon ${ }^{2}$, James B. Cotner, Jr ${ }^{3}$, \\ Joann F. Cavaletto ${ }^{1}$, Jeffrey R. Johnson ${ }^{4}$ \\ 'NOAA Great Lakes Environmental Research Laboratory, 2205 Commonwealth Blvd, Ann Arbor, Michigan 48105, USA \\ ${ }^{2}$ Marine Science Institute, University of Texas at Austin, Port Aransas, Texas 78373, USA \\ ${ }^{3}$ Department of Wildlifie and Fisheries Sciences, Texas A\&M University, College Station, Texas 77843, USA \\ ${ }^{4}$ Cooperative Institute for Limnology and Ecosystem Research, University of Michigan, Ann Arbor, Michigan 48105, USA
}

\begin{abstract}
The dynamics of $N$ and its interactions with labile dissolved organic $C$ (DOC), bacteria, and phytoplankton were studied to determine potential effects of dissolved organic matter (DOM) and light on $N$ dynamics in surface waters of the Mississippi River (USA) plume in the Gulf of Mexico. Bacterial uptake of added labeled $\mathrm{N}$ compounds $\left({ }^{15} \mathrm{NH}_{4}{ }^{+}\right.$or ${ }^{15} \mathrm{~N}$-labeled dissolved free amino acids, DFAA) was stimulated more by high-molecular-weight (HMW, $>1 \mathrm{kDa}$ ) DOM than by low-molecular-weight (LMW, $<1 \mathrm{kDa}$ ) DOM. An index that inversely indicated the presence of labile DOC was defined as the fraction of assimilated Amino acid- ${ }^{15} \mathrm{~N}$ that was Recovered as ${ }^{15} \mathrm{~N}$-Ammonium (ANRA), following the additions of high-levels $(4 \mu \mathrm{M})$ of ${ }^{15} \mathrm{~N}$-DFAA. ANRA ratios were high in the absence of other available carbon sources because heterotrophic bacteria were forced to use the added amino acids as a carbon source for respiration rather than as a nutrient source for biomass formation. In dynamic light/dark experiments, conducted with in situ populations of organisms, uptake rates of added ${ }^{15} \mathrm{NH}_{4}{ }^{+}$were significantly enhanced both by the presence of light and by the addition of HMW DOM. Uptake rates of added ${ }^{15} \mathrm{~N}$-labeled DFAA were increased by the addition of HMW DOM but not by light. ANRA ratios were consistently lower in the presence of added HMW DOM than in controls. Added HMW DOM thus appeared to stimulate the incorporation of assimilated DFAA into bacterial biomass. Bacterial growth rates were relatively high in both light and dark bottles with DFAA additions and in light bottles with HMW DOM plus $\mathrm{NH}_{4}{ }^{+}$additions, but they remained comparatively low in dark bottles with added $\mathrm{NH}_{4}{ }^{+}$These results are consistent with the idea that bacterial $\mathrm{N}$ dynamics in these euphotic waters may be tightly coupled to photosynthetic activities over short time scales.
\end{abstract}

KEY WORDS: Dissolved organic carbon - Nitrogen cycling A Ammonium Bacteria Phytoplankton Amıno acids

\section{INTRODUCTION}

A large fraction of organic material from primary production in aquatic ecosystems is thought to cycle through dissolved organic matter (DOM) and subsequently through heterotrophic bacteria (Scavia \& Laird 1987. Chin-Leo \& Benner 1992, Chróst \& Rai 1993), but biogeochemical mechanisms responsible for these interactions in surface waters are not yet well defined

·E-mail:gardner@glerl.noaa.gov
(Münster \& Chróst 1990). The bulk of the DOM in the ocean is considered to be quite resistant to bacterial breakdown (Menzel 1974 and references therein) but a significant fraction of the DOM in surface waters can be asssimilated or respired by bacteria within days (Kirchman et al. 1991). Bacterial incubations with isolated DOM that had been fractionated into highmolecular-weight (HMW, $>1 \mathrm{kDa}$ ) and low-molecularweight (LMW, <1 kDa) components indicated that HMW DOM supported much more bacterial growth and respiration than LMW DOM (Amon \& Benner 
1994) These results seem to argue against the paradigm that bacterial growth in natural waters is primarily supported by LMW DOM, but they could be biased by the fact that fluxes of LMW DOM in the water are not necessarily reflected by their concentrations in the water at the time of DOM isolation. If labile LMW DOM compounds are removed from the water as rapidly as they are produced, concentrations could be low in isolated fractions even though their fluxes are quantitively important to bacterial/microbial foodweb dynamics under in situ conditions.

Chemical analysis of HMW DOM isolated from ocean water indicates that it has a high concentration of carbohydrates and C:N ratios of about 15 (Benner et al. 1992). Similarly, HMW dissolved organic carbon (DOC) from Mississippi River (USA) plume surface waters have C:N ratios ranging from 14 to 20 as compared to ratios of 19 to 26 in the river (R. Benner unpubl. data). These ratios are much higher than ratios for bacterial biomass, suggesting that the isolated labile HMW DOM may be an important carbon source for bacteria (Sakugawa \& Handa 1985, Pakulski \& Benner 1994) but less important as a $N$ source. Bacteria that grow on this material therefore must obtain most of their $N$ from inorganic sources or from LMW organic $\mathrm{N}$ compounds that are not retained by the ultrafiltration process (Amon \& Benner 1994).

Recent studies with added ${ }^{15} \mathrm{~N}$ have demonstrated that under natural light, significant dissolved organic nitrogen (DON) is released from phytoplankton (Bronk \& Glibert 1993). This recently released DON may be assimilated or metabolized by bacteria (Keil \& Kirchman 1991, 1993, Simon \& Rosenstock 1992) or possibly by phytoplankton (Palenik \& Morel 1990a, b) and reincorporated into the food web via the microbial loop (Bronk et al. 1994). These apparent differences in the dynamics of DOC and DON may be explained by a partial chemical uncoupling of DON and DOC as microbial substrates (Kirchman et al. 1991). For example, rapid cycling of labile, photosynthetically produced LMW DOM, e.g DFAA, may be an important component of DON turnover (Fuhrman 1990, Kirchman et al. 1990).

To gain further insights about $\mathrm{N}$ transformations mediated by primary producers and heterotrophic bacteria, we conducted 2 types of experiment: in the first 'fractionated-DOM-bacterial' experiments, we examined microbial-nitrogen interactions with HMW and LMW DOM, respectively, that had been isolated from the water at a discrete time point. Autotrophic DOM production was prevented during these incubations by the absence of light and by the removal of organisms larger than bacteria. In the second 'natural-biota' experiments, we conducted light and dark ${ }^{15} \mathrm{~N}$ isotope addition experiments on unfiltered surface waters in the presence and absence of added HMW DOM that had been isolated from seawater at the site. These experiments included natural organisms and allowed photosynthesis and associated DOM production/microbial interactions to continue in the lighted bottles.

Comparison of results from these 2 types of experiment provides insights about the dynamic role of HMW DOM and light-driven photosynthetic processes in the short-term turnover of inorganic and organic $\mathrm{N}$ compounds. In this paper, we specifically consider the following questions for surface waters in the Mississippi River plume: (1) is HMW DOM a source or sink for dissolved inorganic $N$ compounds? (2) Do bacteria use different organic substrates for growth (biomass formation) and energy (metabolism) in surface waters? (3) Are bacterial production and heterotrophic $\mathrm{N}$ cycling rates directly enhanced by photosynthetic production of available DOC or DON?

\section{METHODS}

Study sites and DOC analysis. Experiments were conducted on board the RV 'Longhorn' in July 1993 in the northern Gulf of Mexico in the vicinity of the Mississippi River plume. Samples were collected at 2 sites (Table 1) of intermediate salinity where surface-water primary production (Lohrenz et al. 1990), bacterioplankton production (Chin-Leo \& Benner 1992), and nutrient cycling rates (Cotner \& Gardner 1993) are high relative to corresponding rates in surrounding waters. DOC was measured in treatment-bottle waters with a Shimadzu TOC 5000 analyzer (Benner \& Strom 1993)

Table 1. Sample site locations and surface-water characteristics for the fractionated-DOM-bacterial (FDOMB) and natural-biota experiments. Note, the experimental precision of the DOC measurements is less than $2 \%$ coefficient of variation

\begin{tabular}{|lcc|}
\hline & $\begin{array}{c}\text { FDOMB } \\
\text { experiment }\end{array}$ & $\begin{array}{c}\text { Natural-biota } \\
\text { experiment }\end{array}$ \\
\hline Sampling date & July 14,1993 & July 23,1993 \\
Sampling coordinates & $29^{\circ} 10.3^{\prime} \mathrm{N}$, & $28^{\circ} 49.5^{\prime} \mathrm{N}$, \\
& $91^{\circ} 298^{\prime} \mathrm{W}$ & $92^{\circ} 05.84^{\prime} \mathrm{W}$ \\
Temperature $\left({ }^{\circ} \mathrm{C}\right)$ & 30 & 30 \\
Salinity $(\mathrm{psu})$ & 8 & 24 \\
DOC conc. & LMW DOM: 175 & No added HMW DOM: 246 \\
$\left(\mu \mathrm{g}\right.$-atom $\left.\mathrm{Cl}^{-1}\right)$ & HMW DOM: 269 & With added HMW DOM: 525 \\
\hline
\end{tabular}


Nitrogen transformation experiments. In the 'fractionated-DOM-bacterial' experiment, HMW (>1 kDa) DOM was physically separated from LMW $(<1 \mathrm{kDa})$ DOM, diluted back to natural concentrations in artificial seawater, and incubated in the dark as previously described (Amon \& Benner 1994). Seawater was filtered through a $0.1 \mu \mathrm{m}$ pore-size hollow-fiber filter to remove particles, and the DOM was partitioned into HMW and LMW fractions by tangential-flow ultrafiltration (Benner 1991). A 2.51 concentrate of HMW DOM was then diluted to natural concentrations with ca 151 of artificial seawater. LMW DOM remained in the original seawater after ultrafiltration. Each fraction was inoculated with a natural bacterial assemblage $(<0.6 \mu \mathrm{m})$ that had been isolated from the initial water sample. The DOC concentrations in incubations with HMW and LMW DOM were 269 and $175 \mu \mathrm{MC}^{-1}$, respectively (Table 1 ).

Isotope dilution and enrichment experiments, with ${ }^{15} \mathrm{NH}_{4}{ }^{+}$or ${ }^{15} \mathrm{~N}$-labeled amino acid additions to the fractionated-DOM treatments, were conducted in the dark at in situ temperatures. After natural bacteria had been added to both treatments (Amon \& Benner 1994), subsamples $(70 \mathrm{ml})$ from each were placed in $75 \mathrm{ml}$ tissue culture bottles and treated with $4 \mu \mathrm{M}$ levels of either ${ }^{15} \mathrm{NH}_{4}{ }^{+}$or ${ }^{15} \mathrm{~N}$-labeled DFAA (MSD Isotopes MN-2625 Algal Amino Acid Mixture). Each isotope-addition experimental treatment was run in triplicate bottles for experimental replication. Ammonium and DFAA concentrations and ammonium isotope ratios $\left(\left[{ }^{15} \mathrm{NH}_{4}{ }^{+}\right]\right.$: [total $\mathrm{NH}_{4}^{+}$]) were monitored a few minutes after addition of the labeled compounds and at 2 or 3 additional intervals over 20 to $24 \mathrm{~h}$.

'Natural-biota' isotope dilution and enrichment experiments were conducted similarly in a shipboard incubator both under natural light and in the dark with natural seawater (controls) and with natural seawater treated with concentrated HMW DOM isolated from the same sites (Table 1). An assumption for these experiments is that $\mathrm{NH}_{4}{ }^{+}$can be assimilated by either phytoplankton or bacteria, whereas DFAA are more likely to be assimilated by bacteria (Wheeler \& Kirchman 1986). Relative bacterial growth rates were measured after incubations of ca $24 \mathrm{~h}$ to provide insights about the interactive effects of added HMW DOM, N (in the form of $\mathrm{NH}_{4}{ }^{+}$or DFAA), and light on bacterial growth rates.

To measure dissolved $\mathrm{NH}_{4}{ }^{+}$and DFAA concentrations and $\left[{ }^{15} \mathrm{NH}_{4}{ }^{+}\right]$: [total $\left.\mathrm{NH}_{4}{ }^{+}\right]$ratios, $10 \mathrm{ml}$ of water were sampled from each treatment and passed through a $0.2 \mu \mathrm{m}$ pore-size nylon filter $(25 \mathrm{~mm}$ diameter). The first $3 \mathrm{ml}$ was used to rinse the filter and the next $7 \mathrm{ml}$ was collected in a clean $8 \mathrm{ml}$ vial (Wheaton \# 224884). Ammonium and DFAA concentrations were measured on-board ship (Gardner \& St. John 1991), and the remaining filtrate was frozen for later isotope ratio analysis by high performance liquid chromatography (HPLC; Gardner et al. 1991, 1993). Community ammonium regeneration and potential uptake rates in the bottles were calculated from changes in dissolved ammonium concentrations and isotope ratios over time using the Blackburn-Caperon model (Blackburn 1979, Caperon et al. 1979).

Calculation of the percentage of assimilated Amino acid- ${ }^{15} \underline{\underline{N}}$ Recovered as ${ }^{15} \mathrm{~N}$-Ammonium (ANRA) in DFAA addition experiments. Isotope enrichment experiments with relatively high-level additions of ${ }^{15} \mathrm{~N}$-labeled DFAA can provide useful information on the 'maximum uptake velocity' ( $V_{\max }$ ) of DFAA by the bacterial community (Wright \& Hobbie 1965) and can also provide a qualitative indication of the relative availability of other naturally occurring labile DOC substrates to the bacterial community (see discussion below). These experiments differ from typical radioactive tracer studies of amino acid dynamics in that they are used as an indicator of the presence or supply rates of labile organic carbon rather than as a tool to trace the in situ dynamics of natural amino acids in the water. The use of 'saturating' rather than 'tracer' concentrations of DFAA minimizes isotope dilution of the added DFA.A with natural DFAA and allows estimation of $V_{\max }$ for DFAA in the water. In addition, the fate of ${ }^{15} \mathrm{~N}$ rather than of ${ }^{14} \mathrm{C}$ or ${ }^{3} \mathrm{H}$ from the added labeled amino acids is followed. The concentrations of amino acids $(4 \mu \mathrm{M})$ that were added are high relative to natural concentrations of amino acids, but are reasonable, relative to potential turnover rates, for these summer experiments in Mississippi River plume surface waters (Cotner \& Gardner 1993).

The ANRA ratio provides an index that can be assumed to be inversely related to the amounts or supply rates of non-amino labile organic compunds that are available to bacteria if effects of bacterial grazers and uptake of ammonium by phytoplankton are accounted for. If the added amino acids $(\mathrm{C}: \mathrm{N}$ ratio $=$ 4.30 ) become the predominant forms of carbon that are available to bacteria, a high percentage of the amino acid carbon will be metabolized, to meet respiration/ deamination energy requirements, and a correspondingly high percentage of the ${ }^{15} \mathrm{~N}$ added as amino acids will in turn be mineralized to ammonium (e.g Zehr et al. 1985. Goldman et al. 1987). For example, in the Mississippi River plume region, about $90 \%$ of the 'assimilated" ${ }^{15} \mathrm{~N}$ that had been added as labeled amino acids was recovered as ${ }^{15} \mathrm{NH}_{4}{ }^{+}$in bottle experiments with dark subsurface waters as compared to about $48 \%$ in surface waters under natural light (Gardner et al. 1993). Similarly, organic substrate-depleted Lake Michigan bacteria regenerated an amount of ammonium approximately equivalent to the amount of added 
DFAA consumed (Gardner et al. 1987, 1989). Conversely, if other sources of labile carbon are available to be metabolized, more of the amino- $\mathrm{N}$ can be incorporated into biomass (see 'Results')

ANRA, expressed as \%, was calculated as follows:

$\mathrm{ANRA}=\left\{\left(\left[\mathrm{NH}_{4}{ }^{+}\right]_{\mathrm{f}} \times R_{\mathrm{f}}\right)-\left(\left[\mathrm{NH}_{4}{ }^{+}\right]_{1} \times R_{\mathrm{i}}\right)\right\} /\left([\mathrm{AAA}]_{\mathrm{i}}-[\mathrm{AA}]_{\mathrm{f}}\right) \times 100$

where $\left[\mathrm{NH}_{4}{ }^{+}\right]_{\mathrm{r}}$ is the concentration of $\mathrm{NH}_{4}{ }^{+}$at the sampling point where DFAA had reached background for near-background) levels, $R_{f}$ is the isotope ratio of $\left[{ }^{15} \mathrm{NH}_{4}{ }^{+}\right.$]: [total $\mathrm{NH}_{4}{ }^{+}$] at the same sampling point that $\left[\mathrm{NH}_{4}{ }^{+}\right]_{\mathrm{f}}$ was determined, $\left[\mathrm{NH}_{4}{ }^{+}\right]_{1}$ is the concentration of $\mathrm{NH}_{4}{ }^{+}$at the initial sampling point, $R_{\mathrm{i}}=$ isotope ratio of $\left[{ }^{15} \mathrm{NH}_{4}{ }^{+}\right]$:[total $\left.\mathrm{NH}_{4}{ }^{+}\right]$at the initial sampling point, $[\mathrm{AA}]_{\mathrm{i}}$ is the measured DFAA concentration at the initial sampling point, and $[A A]_{f}$ is the measured amino acid concentration at the sampling point where DFAA concentrations had reached near-background levels. In using this equation, we assume that changes in DFAA levels are caused by uptake of the added ${ }^{15} \mathrm{~N}$-labeled amino acids. If initial concentrations of DFAA are higher than $4 \mu \mathrm{M}$ plus the background, i.e. if measurable natural UFAA are present in the water in addition to the background fluorescent response typically observed for non-labile compunds (Gardner \& St. John 1991, Keil \& Kirchman 1993), the decreases can exceed $4 \mu \mathrm{M}$ due to the presence of non-labeled labile amino acids. When measurable unlabeled DFAA were present in any of the treatments, we assumed that $[A A]_{i}-[A A]_{f}=4 \mu \mathrm{M}$ for the calculation, since the change in ${ }^{15} \mathrm{~N}$-labeled amino acids cannot exceed the amount that was initially added. The background response was equivalent to that from DFAA levels of 0.4 and $0.8 \mu \mathrm{M}$, respectively, in waters used for the fractionated-DOM-bacterial and natural-biota experiments. Note, ANRA ratios should be considered as a qualitative rather than an absolute indicator of substrate availability because their values can also be affected to some extent by other factors such as isotope dilution of the DFAA pool, mineralization of assimilated amino acids by bacterial grazers, and/or uptake of ${ }^{15} \mathrm{NH}_{4}{ }^{+}$by phytoplankton in experiments with natural assemblages of organisms. To minimize the effects of these factors, we calculated ANRA at the first point where DFAA were reduced to near-background levels and conducted some experiments in the dark as well as under natural light conditions.

Bacterial abundances, growth rates, and amino acid turnover rates. Bacterial abundances were estimated with acridine orange staining and epifluorescence microscopy of duplicate samples (Hobbie et al. 1977). Relative bacterial production rates were estimated from rates of incorporation of ${ }^{3} \mathrm{H}$-thymidine into DNA (Fuhrman \& Azam 1982). Samples were incubated in duplicate with $20 \mathrm{nM}$ (final concentration) of [methyl-
${ }^{3}$ H]thymidine (TdR) (Amersham). Nucleic acid and protein fractions were separated with a trichJoroacetic acid extraction procedure (Chin-Leo \& Benner 1992). Killed blanks were used to correct for abiotic adsorption to filters. In killed controls, formalin was added to a final concentration of $4 \%, 15$ to 20 min prior to the addition of radioisotope.

Amino acid turnover rates were estimated with a mixture of ${ }^{3} \mathrm{H}$-labeled DFAA from algal protein hydrolysate (Amersham). Tracer amounts (less than 1 nM final concentration) were added to duplicate samples and incubated for 10.0 min at ambient temperature. Incubations were terminated by filtration onto a $0.2 \mu \mathrm{m}$ pore-size filter (Millipore GSWP). Duplicate filter and filtrate samples were collected and frozen prior to further analyses. Filters were dissolved with $1 \mathrm{ml}$ ethylacetate before radioassay. Turnover rates were corrected for respired amino acids by allowing a $1 \mathrm{ml}$ sample to equilibrate with $2 \mathrm{ml}$ of distilled water through the gaseous phase by a modification of the procedure of Ashcroft et al. (1972). The filtrate of a labeled sample was preserved ( $2 \%$ formalin final concentration) and placed in a $1.5 \mathrm{ml}$ open centrifuge tube inside of a closed $20 \mathrm{ml}$ scintillation vial containing distilled water. The respired tritium $\left({ }^{3} \mathrm{H}-\mathrm{H}_{2} \mathrm{O}\right)$ was allowed to equilibrate at $25^{\circ} \mathrm{C}$ for 1 mo. Samples from the inner and outer vials were analyzed in a liquid scintillation counter. All dpm (disintegrations per minute) in the large vial were assumed to be from ${ }^{3} \mathrm{H}-\mathrm{H}_{2} \mathrm{O}$. The fraction of amino acids respired was calculated as $\left(d p m_{D W}\right) /\left(d p m_{P}+d p m_{F}\right)$, where $d p m_{D W}$, $d p m_{P}$ and $d p m_{F}$ are $d p m$ in distilled water, on the filter and in the filtrate, respectively. All samples were corrected for background levels of ${ }^{3} \mathrm{H}-\mathrm{H}_{2} \mathrm{O}$ by analysis of killed controls. Background levels were less than $5 \%$ of the total dpm. Incorporation was calculated as $d p m_{p} /\left(d p m_{p}+d p m_{F}\right)$, and efficiency was estimated as Incorporation/(Incorporation + Respiration).

\section{RESULTS}

\section{Fractionated-DOM-bacterial experiment}

Except for an increase at the second sampling point, the concentrations of added $\mathrm{NH}_{4}{ }^{+}$remained relatively constant in the seawater containing LMW DOM in the ${ }^{15} \mathrm{NH}_{4}{ }^{+}$treatments (Fig. 1). However, in the water containing HMW DOM, $\mathrm{NH}_{4}{ }^{+}$was removed to near-background levels during the $20 \mathrm{~h}$ incubation. This result is consistent with the hypothesis that HMW DOM is an 'available' organic substrate with a high $\mathrm{C}: \mathrm{N}$ ratio that causes microbes to assimilate $\mathrm{NH}_{4}{ }^{+}$In contrast, LMW DOM must have either been unavailable or had a relatively low $\mathrm{C}: \mathrm{N}$ ratio so that the bacteria did not require 


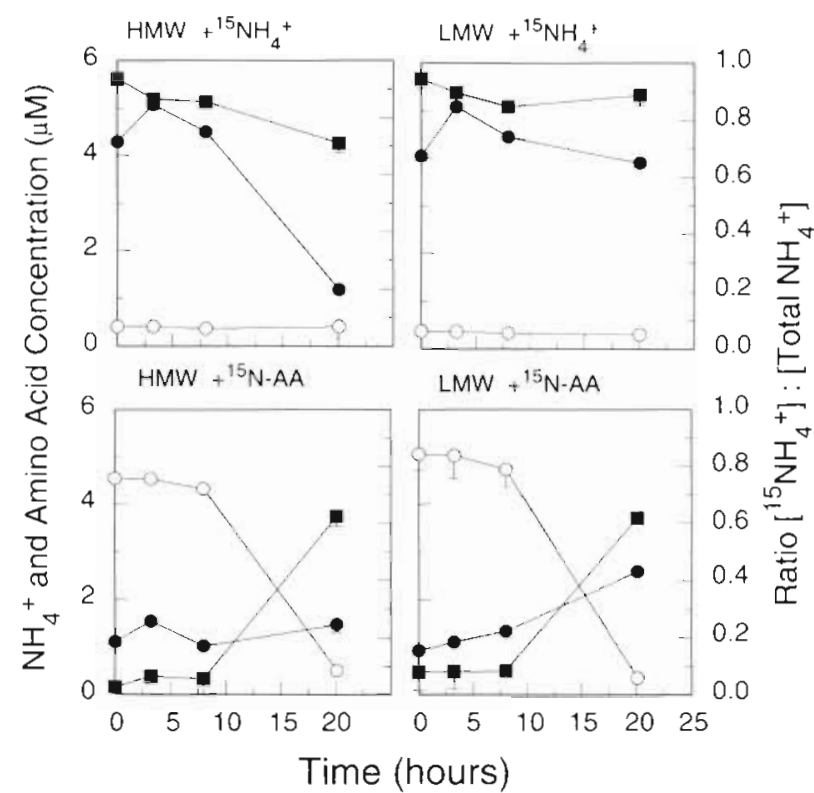

Fig. 1. Time-course results for ammonium (-) and amino acid (O) concentrations and ${ }^{15} \mathrm{NH}_{4}{ }^{+}$isotope ratios (a) for the fractionated-DOM-bacterial experiment with HMW and LMW DOM treatment waters treated with either ${ }^{15} \mathrm{NH}_{4}{ }^{*}$ or ${ }^{15} \mathrm{~N}$ labeled amino acids and incubated for $20 \mathrm{~h}$

additional N. Removal patterns for ${ }^{15} \mathrm{~N}$-labeled DFAA were similar in both treatments. After an initial lag. probably due to relatively low bacterial numbers removal rates were high; the added DFAA ( $4 \mu \mathrm{M})$ were completely removed within about $20 \mathrm{~h}$ (Fig. 1). The ANRA ratios were higher in the LMW DOM treatment $(40 \%)$ than in the HMW DOM treatment $(22 \%)$ where $\mathrm{NH}_{4}{ }^{+}$concentrations did not appreciably increase (Table 2).

For the LMW DOM treatment, $\mathrm{NH}_{4}^{+}$regeneration rates decreased from about $60 \mathrm{nM} \mathrm{h}^{-1}$ in the first 2 invervals to approximately 0 in the third interval (Fig. 2). This trend may have reflected the depletion of labile organic nitrogen. Ammonium regeneration rates for the HMW DOM treatment varied among replicate measurements and did not show significant changes

Table 2. Summary of ANRA values \pm SE (n in parentheses) expressed as a percentage for the different amino acid addıtion treatments in the the fractionated-DOM-bacterial (FDOMB) and natural-biota experiments. See text for ANRA calculation procedure

\begin{tabular}{|c|c|c|c|c|}
\hline & \multicolumn{2}{|c|}{ Dark } & \multicolumn{2}{|c|}{ Light } \\
\hline & HMW & L.MW & & \\
\hline \multirow[t]{2}{*}{ FDOMB } & $22 \pm 3(3)$ & $40 \pm 2(3)$ & & \\
\hline & HMW & Control & HMW & Control \\
\hline Natural-biota & $36 \pm 2(2)$ & $65 \pm 2\{3\}$ & $27 \pm 3(3)$ & $61 \pm 4(2)$ \\
\hline
\end{tabular}

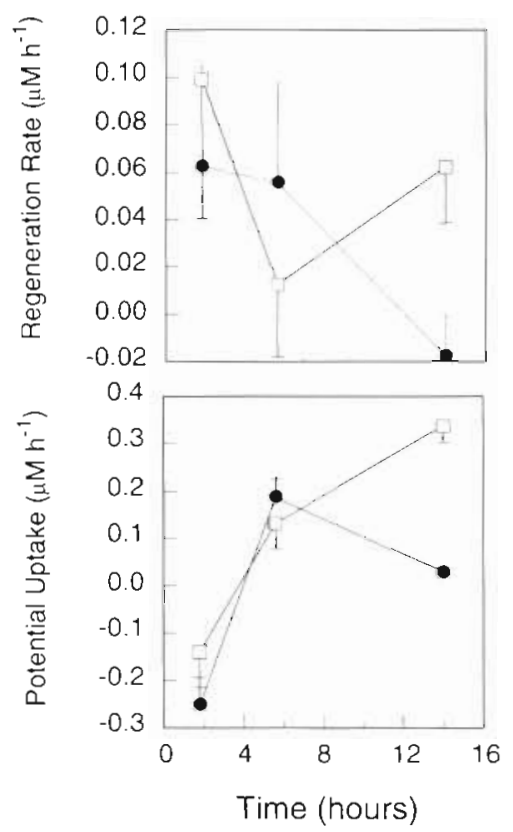

Fig. 2. Mean potential uptake and regeneration rates for the ammonium-addition experiments during incubations for HMW DOM (口) and LMW DOM ( treatments calculated from data presented in Fig. 1. Rates were calculated from changes in ammonum concentrations and isotope ratios using the model of Blackburn (1979)

between initial and final time points. Calculated uptake rates for $\mathrm{NH}_{4}{ }^{+}$ranged from $<0$ during the first interval for both treatments, when bacterial abundances were relatively low, to about $0.2 \mu \mathrm{M} \mathrm{h}^{-1}$ for the second interval and to $0.3 \mu \mathrm{M} \mathrm{h}^{-1}$ for the HMW DOM at the third interval (Fig. 2). Uptake rates decreased after $6 \mathrm{~h}$ for the LMW DOM treatment but continued to increase during the second interval in the HMW DOM treatment, reflecting changes in bacterial nutritional status for the 2 types of treatment (Amon \& Benner 1994)

Relative bacterial growth rates and amino acid incorporation and respiration rates, determined with tracer levels of ${ }^{3} \mathrm{H}$-labeled DFAA (Cotner \& Gardner 1993), were measured after incubating the fractionated material for $1 \mathrm{~d}$. Bacterial abundances and thymidine incorporation rates were both substantially higher in the HMW DOM treatments than in the LMW DOM treatments (Fig. 3a). Amino acid incorporation and respiration rates, and amino acid incorporation efficiencies, were all higher in the HMW DOM treatments than in the LMW DOM treatments (Fig. 3b).

\section{Natural-biota experiment}

Ammonium was removed fastest from the lighted bottles with added HMW DOM and slowest from control water in the dark (Fig. 4). More $\mathrm{NH}_{4}{ }^{+}$was removed 

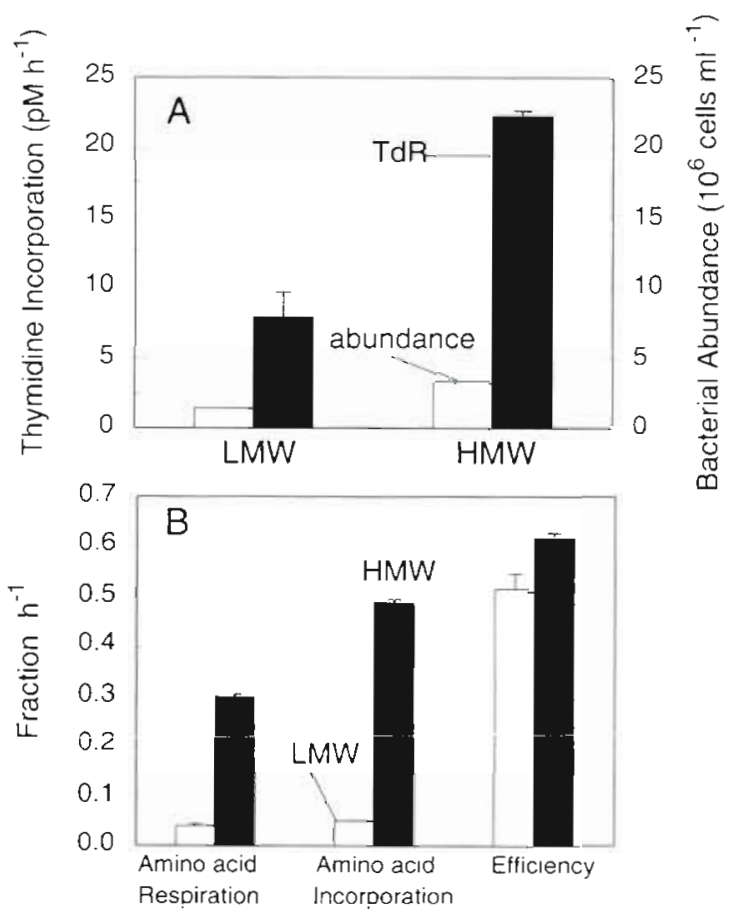

Fig. 3. (A) Bacterial abundances and thymidine incorporation. rates and (B) amino acid respiration and incorporation rates and calculated incorporation efficiencies I= Incorporation/ (Incorporation + Respiration)] for ${ }^{3} \mathrm{H}$-labeled amino acids after treatment waters from the fractionated-DOM-bacterial experiment were incubated for about $24 \mathrm{~h}$ in the dark

from solution in bottles containing HMW DOM and in lighted bottles than in control seawater treatments. The same trends were seen in isotope ratios indicating isotope dilution of ${ }^{15} \mathrm{NH}_{4}{ }^{+}$with ${ }^{14} \mathrm{NH}_{4}{ }^{+}$in all of the treatments.

Ammonium regeneration and potential uptake rates were calculated over the first $10 \mathrm{~h}$ because changes over the first $2.5 \mathrm{~h}$ interval were not sufficient to produce an adequate signal-to-noise ratio to allow recognition of significant trends. A 2-way ANOVA, testing the effects of light ( $p=0.13$ ) and HMW DOM additions $(p=0.22)$ over the $10 \mathrm{~h}$ interval, did not show significant differences in $\mathrm{NH}_{4}{ }^{+}$regeneration rates. The HMW dark treatment showed lower regeneration

Table 3. Ammonium regeneration and uptake rates $\left(\mu \mathrm{M} \mathrm{NH}_{4}^{+} \mathrm{h}^{-1}\right) \pm \mathrm{SE}$ in natural-biota experiments for Control and HMW treatment bottles incubated in the dark and under natural light conditions. Note, these data were calculated from the ammonium-addition expenments presented in Fig. 4

\begin{tabular}{|lllll|}
\hline & \multicolumn{2}{c}{ Dark } & \multicolumn{2}{c|}{ Light } \\
& Control & HMW & Control & HMW \\
\hline $\begin{array}{l}\text { Regeneration rate } \\
\text { Uptake rate }\end{array}$ & $0.08 \pm 0.04$ & $0.05 \pm 0.002$ & $0.13 \pm 0.02$ & $0.09 \pm 0.03$ \\
& $0.09 \pm 0.04$ & $0.18 \pm 0.01$ & $0.23 \pm 0.02$ & $0.29 \pm 0.02$ \\
\hline
\end{tabular}

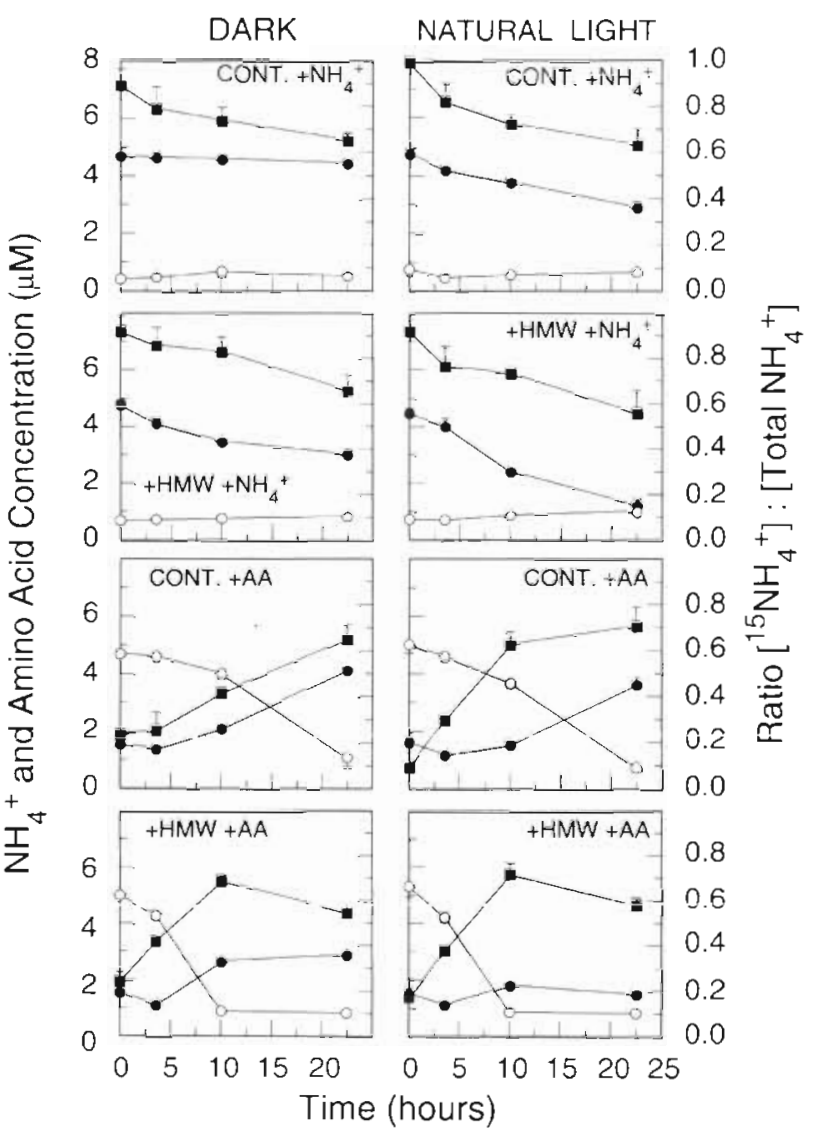

Fig. 4. Time-course results for ammonium ( $\bullet$ and amino acid (O) concentrations and ${ }^{15} \mathrm{NH}_{4}{ }^{+}$isotope ratios (a) for the natural-biota experiment conducted in the dark and under natural light and in the presence and absence of added HMW DOM. Treatment waters were fortified with either ${ }^{15} \mathrm{NH}_{4}{ }^{+}$or

${ }^{15} \mathrm{~N}$-labeled amino acids and incubated for $23 \mathrm{~h}$

rates than the light treatments but SEs for the other. treatments overlapped (Table 3). In contrast, uptake rates during the same interval showed significant differences for both light ( $p=0.0013$ ) and HMW DOM additions ( $p=0.019$ ) with progressive increases from the dark control to the light HMW addition treatment (Table 3). The presence of natural light had a slightly greater effect than the addition of HMW DOM but results from the 2 treatments were generally additive, i.e. interactions between the 2 treatments were not significant ( $p=0.59$ ). Interestingly, in the dark control treatments, uptake and regeneration rates were not significantly different from each other, but in all other treatments potential uptake rates were significantly higher than the regeneration rates (Table 3 ).

Removal rates for added DFAA, which reflected the $V_{\max }$ of the bacterial community for DFAA, were high, particularly in 
the HMW DOM treatments where DFAA were completely removed in about $10 \mathrm{~h}$ (Fig. 4). By comparison, more than $20 \mathrm{~h}$ was needed for complete removal of the added DFAA in the controls. The fact that HMW DOM addition immediately enhanced the DFAA removal rates (i.e. during the first interval) suggests that the native bacterial populations were already adapted to using DFAA at relatively high rates in the presence of natural HMW DOM. The DFAA removal patterns were similar in light and dark bottles for both control and HMW DOM treatments.

Isotope ratios of $\mathrm{NH}_{4}{ }^{+}$generally increased in proportion to decreases in ${ }^{5} \mathrm{~N}$-labeled DFAA concentrations. However, $\mathrm{NH}_{4}{ }^{+}$accumulation from DFAA degradation was minimal in the treatments with added HMW DOM. More $\mathrm{NH}_{4}{ }^{+}$accumulated in the dark than in the light and in the controls than in the waters treated with HMW DOM (Fig. 4). The ANRA ratios were about 36 and $26 \%$ in the dark and light HMW DOM treatments as compared to 64 and $61 \%$ in the corresponding control treatments (Table 2). In the treatments with added HMW DOM, the isotope ratios increased proportionately with the decreases in DFAA concentrations, but then decreased slightly after the DFAA were depleted to background levels (Fig 4). This decrease can be attributed to isotope dilution of the ${ }^{15} \mathrm{NH}_{4}{ }^{+}$that was in solution after degradation of the ${ }^{15} \mathrm{~N}$-labeled DFAA. Final $\mathrm{NH}_{4}{ }^{+}$concentrations were similar in comparable treatments whether $\mathrm{NH}_{4}{ }^{+}$or DFAA was the initial source of available $\mathrm{N}$ (Fig. 4)

\section{Effects of light and HMW DOM additions on relative bacterial growth rates}

Relative bacterial growth rates were measured in all of the above treatments that had been enriched with ${ }^{15} \mathrm{NH}_{4}{ }^{+}$or ${ }^{15} \mathrm{~N}$-labeled DFAA and incubated for about $24 \mathrm{~h}$ under light (natural) or dark conditions (Table 4). The highest growth rates were observed in bottles incubated in the light with added HMW DOM and DFAA. Similar high growth rates were observed in lighted bottles containing HMW DOM and added $\mathrm{NH}_{4}^{+}$Much lower rates were observed in the dark bottles with $\mathrm{NH}_{4}{ }^{+}$ additions (with or without added HMW DOM) and in the light treatment without HMW DOM. In contrast, relatively high growth rates, comparable to results for light bottles, were observed in dark bottles with added DFAA. Incubations in the light with added $\mathrm{NH}_{4}{ }^{+}$and $\mathrm{HMW}$ DOM produced approximately the same result as adding the DFAA directly.

\section{DISCUSSION}

\section{Is HMW DOM a source or sink for dissolved inorganic nitrogen compounds?}

In agreement with expectations from the chemical analyses showing a high $\mathrm{C}: \mathrm{N}$ ratio and carbohydrate content for HMW DOM (Benner et al. 1992, Pakulski \& Benner 1994), our data suggest that HMW DOM is a source of $\mathrm{C}$ for heterotrophic bacteria that in turn form a biological sink for $\mathrm{NH}_{4}{ }^{+}$. Bacterial abundances and growth rates increased much more in the presence of isolated HMW DOM than in the presence of natural levels of LMW DOM (Amon \& Benner 1994). In all of our experiments with $\mathrm{HMW}$ DOM, $\mathrm{NH}_{4}^{+}$concentrations decreased more in the presence of added HMW DOM than they did in its absence. The contention that HMW DOM is an available $C$ source for bacteria is supported by the fact that it caused increased uptake of both forms of $\mathrm{N}$ in the natural-biota experiments but did not enhance $\mathrm{NH}_{4}{ }^{+}$regeneration rates.

The presence of HMW DOM in experiments with DFAA additions greatly enhanced the $V_{\max }$ of the bacterial community for DFAA uptake and consistently caused ANRA ratios to be lower than was observed in comparable control bottles without HMW DOM additions. In the fractionated-DOM-bacterial experiment, removal patterns for ${ }^{15} \mathrm{~N}$-labeled DFAA were similar in both treatments but ANRA ratios were higher with LMW DOM (40\%) than with HMW DOM (22\%). The HMW DOM apparently enabled more of the DFAA-N to be incorporated into biomass than did the LMW DOM. Thymidine incorporation rates and DFAA incorporation and respiration rates were all higher in the HMW DOM treatments than in the LMW DOM treatment. The incorporation efficiency (ratio of DFAA incorporation rate: DFAA incorporation rate + respiration rate) was also slightly higher for the HMW DOM than for the isolated LMW DOM. These results are consistent with the idea that HMW DOM is a bioavailable substrate with a relatively high C:N ratio (Amon \& Benner 1994) but did not provide evidence for high reactivity of isolated LMW DOM.

Table 4. Relative bacterial growth rates $\left(\mathrm{pM} T d R \mathrm{~h}^{-1}\right) \pm S E$ in control and HMW natural-biota experiments incubated in the dark and under natural light conditions with $4 \mu \mathrm{M}$ additions of ${ }^{15} \mathrm{NH}_{4}{ }^{+}$or ${ }^{15} \mathrm{~N}$-labeled amino acids. See Fig. 4 legend for information on sample treatments

\begin{tabular}{|ccccc|}
\hline & \multicolumn{2}{c}{ Dark } & \multicolumn{2}{c|}{ Light } \\
& Control & HMW & Control & HMW \\
\hline$+{ }^{15} \mathrm{NH}_{4}{ }^{+}$ & $33 \pm 8$ & $26 \pm 9$ & $47 \pm 12$ & $131 \pm 32$ \\
$+{ }^{15} \mathrm{~N}$-labeled amino acids & $106 \pm 10$ & $125 \pm 14$ & $92 \pm 9$ & $156 \pm 2$ \\
\hline
\end{tabular}


In our natural-biota experiment, ANRA in the dark was higher in the control treatments $(64 \%)$ than in the ones treated with HMW DOM $(36 \%)$. Both of these percentages were higher than the corresponding conversions observed in the fractionated-DOM-bacterial experiment. This difference could result from sampling site differences or more likely from the fact that remineralizing micrograzers were present in the natural-biota experiment but were removed before incubations in the fractionated-DOM-bacterial experiment. Likewise, in the light ANRA was higher in the control $(61 \%)$ than in the HMW DOM treatment $(26 \%)$. The observation that ANRA was consistently higher in control treatments than in the HMW DOM ones suggests that HMW DOM enhanced incorporation of amino acid nitrogen into bacterial biomass (vs respiratory loss of the organic nitrogen as $\mathrm{NH}_{4}^{+}$). The similarity of ANRA values in comparable light and dark treatments (Table 2) indicates that a relatively small portion of the mineralized ammonium was taken up by phytoplankton before ANRA measurements were made.

\section{Do bacteria use different organic substrates for growth and energy in surface waters?}

The experiments described here in conjunction with the corresponding data of Amon \& Benner (1994) suggest that the dynamics of DOC and DON are partially uncoupled (Kirchman et al. 1991). The HMW DOM that can be isolated by ultrafiltration consists largely of carbohydrates and has a relatively high $\mathrm{C}: \mathrm{N}$ ratio (Benner et al. 1992). This fresh material appears to be an important source of $\mathrm{C}$ for bacteria but does not appear to provide sufficient $\mathrm{N}$ for bacterial growth. Thus, $\mathrm{N}$ must come from inorganic forms or from other sources such as DFAA or peptides (Coffin 1989, Keil \& Kirchman 1991, Rosenstock \& Simon 1993). Of course, the dynamics of DOC and DON cannot be completely uncoupled if labile LMW DON compounds such as DFAA or peptides are quantitatively important metabolites because these compounds contain both organic $\mathrm{C}$ and $\mathrm{N}$.

Studies examining the fate of ${ }^{15} \mathrm{NH}_{4}{ }^{+}$and ${ }^{15} \mathrm{NO}_{3}{ }^{-}$in isotope addition experiments suggest that a substantial fraction of the ${ }^{15} \mathrm{~N}$ incorporated into organisms under. natural light is released as ${ }^{15} \mathrm{~N}$-DON with relatively short turnover times (Bronk \& Glibert 1993, Bronk et al. 1994). This DON release can result as a by-product of feeding by zooplankton or protozoans (Nagata \& Kirchman 1991, Bronk \& Glibert 1993) that tend to release HMW DON, or from passive release of LMW DON by autotrophs (Hellebust 1974, Bronk \& Glibert 1993). Our results in combination with previous analy- sis of HMW DOM (e.g. Benner et al. 1992) suggest that any labile DON that is produced must orcur mainly as short-lived LMW DOM. If substantial DON is released as proteins that are stable for more than a few hours, one would expect HMW DOM isolated by ultrafiltration to have a lower $\mathrm{C}: \mathrm{N}$ ratio than has beem observed (Benner et al. 1992). Likewise, HMW DOM would tend to be a source rather than a sink for nitrogen in dark bottle incubations (Amon \& Benner 1994).

\section{Are bacterial production rates and heterotrophic $\mathrm{N}$ cycling rates directly enhanced by photosynthetic production of available DOC or DON?}

Bacterial numbers and growth rates (Amon \& Benner 1994) and $\mathrm{NH}_{4}{ }^{*}$ uptake rates were directly enhanced by the presence of fresh HMW DOM. The rapid removal of DFAA in both the HMW and $L M W$ treatments in the fractionated-DOM-bacterial experiment suggests that the $V_{\max }$ for DFAA uptake was high, as would be expected at the experimental temperature of $30^{\circ} \mathrm{C}$. As mentioned above, only dibut $22 \%$ of ilue assimilated ${ }^{15} \mathrm{~N}$ from the DFAA was recovered as ${ }^{15} \mathrm{NH}_{4}{ }^{+}$in the HMW DOM treatment as compared to $40 \%$ for the LMW DOM treatment. The presence of HMW DOM as a C source apparently allowed the bacteria to use the DFAA for biomass incorporation more efficiently than when added DFAA alone were the main source of carbon.

The fractionated-DOM-bacterial experiment did not show greatly enhanced microbiological activity or $\mathrm{N}$ cycling rates in the presence of isolated LMW DOM. This observation would seem to argue against the paradigm that microbial processes are driven by LMW organic compounds. However, another feasible explanation for this observation is that bacterial activity decreases when bacterial processes are experimentally uncoupled from autotrophic processes that serve as short-term sources of labile organic materials to the bacteria. Recent studies have shown a close relationship between bacterial production and photosynthetic processes (Cole et al. 1982, 1988, Coffin et al. 1994). If turnover of the labile organic compounds is rapid, and if bacterial uptake rates are as rapid as production rates of the labile compounds, steady-state concentrations of some materials (e.g. DFAA) remain very low even though the actual fluxes of the materials are high Our natural-biota experiments allowed comparison of $\mathrm{N}$ cycling rates during times when active autotrophic production of bacterial substrates should have occurred (light experiments with natural biota) to those when new production of labile organic substrates should have been low (fractionated-DOM-bacterial and dark natural-biota experiments). 
Our ANOVA results indicate that the presence of both light and added HMW DOM increased $\mathrm{NH}_{4}^{+}$ uptake and isotope dilution rates. Light had a slightly greater effect on $\mathrm{NH}_{4}{ }^{+}$uptake rates than added HMW DOM but the effects were comparable and non-interactive. These results suggest that both bacteria and phytoplankton were actively assimilating $\mathrm{NH}_{4}{ }^{+}$in the light with added HNW DOM.

The minimal differences between light and dark DFAA removal patterns that were observed both in the presence and absence of added HMW DOM indicate that heterotrophic bacteria rather than phytoplankton were primarily responsible for DFAA uptake. The high removal rates (i.e. $V_{\max }$ ) for the added DFAA, particularly in the presence of added HMW DOM, suggest that the bacteria may have been accustomed to turning over relatively large quantities of DFAA under natural conditions even though DFAA concentrations are normally low. The HMW DOM apparently increased the efficiency of DFAA uptake by heterotrophic bacteria as DFAA uptake rates approximately doubled when isolated HMW DOM was added. This increase in DFAA uptake rates was already observed during the first $4 \mathrm{~h}$ incubation interval, an indication that the bacteria were likely already adapted to using this combination of substrates (i.e. DFAA with HMW DOM). The ANRA values were consistently lower in HMW DOM treatments than in controls, suggesting that the HMW DOM stimulated the incorporation of amino acid- $\mathrm{N}$ into bacterial biomass. A conceptual model that would explain these observations is that DFA.A, produced by autotrophic processes, are rapidly used by heterotrophic bacteria mainly for biomass formation, particularly when labile HMW DOM with a high $\mathrm{C}: \mathrm{N}$ ratio is available as a source of energy for respiration.

Examination of bacterial growth rates in the different ${ }^{15} \mathrm{~N}$-addition treatments provides revealing insight about the effects of DFAA and autotrophic production processes on bacterial production in these waters. Addition of DFAA stimulated growth rates in all treatments as may be expected if DFAA are a preferred source of $\mathrm{N}$ by bacteria (e.g. Kirchman et al. 1989, Keil \& Kirchman 1991). The addition of HMW DOM appeared to stimulate bacterial growth rates in the presence of added DFAA in the light and dark and in the presence of $\mathrm{NH}_{4}{ }^{+}$in the light but not in the dark. Lowest bacterial growth rates were observed for $\mathrm{NH}_{4}{ }^{+}$ additions in the dark and only slightly higher growth rates were observed for $\mathrm{NH}_{4}{ }^{+}$additions in the light treatment without added HMW DOM. We unfortunately did not measure bacterial production rates in comparable bottles without $\mathrm{N}$ additions and therefore could not determine the extent that $\mathrm{NH}_{4}{ }^{+}$addition stimulated bacterial production rates over those with- out nitrogen additions. However, our results show that $\mathrm{NH}_{4}{ }^{+}$additions to HMW DOM in the light can clearly stimulate bacterial production more than the same additions in the dark.

The increased bacterial production rates in the lighted HMW DOM treatment suggest that autotrophic processes interacted with HMW DOM to enhance bacterial growth rates. Possibly, there was autotrophic conversion of the ${ }^{15} \mathrm{NH}_{4}{ }^{+}$to readily available organic $\mathrm{N}$ compounds such as DFAA in the presence of light and a source of labile carbon. Alternatively, the phytoplankton may have provided the bacteria with other 'growth factors' that allowed them to efficiently assimilate $\mathrm{NH}_{4}{ }^{+}$in the presence of HMW DOM. These data are interesting relative to diel differences in 'bacterial growth capacity' observed for bacteria in microcosms (Zweifel et al. 1993). The growth capacity, defined as the growth yield of bacteria in filtered water relative to natural bacterial abundances in the same water, tended to be lower at night than during the day (Zweifel et al. 1993). Also, in nutrient-enriched mesocosms, bacterial production, $\mathrm{O}_{2}$ consumption, and growth efficiencies were highest during daylight or early evening when substrate availability was highest (Coffin et al. 1994). In Chesapeake Bay, amino acid uptake rates were also higher in daylight than at night (Glibert et al. 1991).

The above experiments suggest that nutrient cycling processes in Mississippi River plume surface waters are closely linked to light-driven organic matter production or conversion by the photosynthetic process. The ANRA index appears to effectively indicate the relative degree that labile DOC was available to support bacterial respiration in the different treatments. HMW DOM appears to be a more important source of $\mathrm{C}$ and energy for bacteria than LMW DOM. In contrast, LMW DOM may be an important $\mathrm{N}$ source for bacteria, as suggested by high $V_{\max }$ values for DFAA and increased incorporation rates of high levels of DFAA into biomass in the presence of HMW DOM. Our data agree with the hypothesis that HMW DOC compounds provide a carbon source to 'fuel' bacterial growth but that rapidly-recycling LMW organic $\mathrm{N}$ compounds (e.g. DFAA), or possibly some other growth factors plus $\mathrm{NH}_{4}{ }^{*}$, are needed for bacterial biomass formation in surface waters of the Mississippi River plume.

Acknowledgements. Thus research was sponsored by the NOAA Coastal Ocean Program through the Nutrient Enhanced Coastal Ocean Program (NECOP). We thank the crew of the RV 'Longhorn' for ship support, Lynn Herche for statistical analyses, and Harvey Bootsma, Peter Landrum, and David Kirchman for constructive comments on the manuscript. This paper is GLERL Contribution No. 937 


\section{LITERATURE CITED}

Amon RMW, Benner R (1994) Major role for high-molecularweight dissolved organic matter in the marine carbon cycle. Nature 369:549-552

Ashcroft SJH, Weerasnghe LCC, Bassett JM, Randle PJ (1972) The pentose cycle and insulin release in mouse pancreatic sslets. Biochem J 126:525-532

Benner R (1991) Ultrafiltration for the concentration of bacteria, viruses, and dissolved organic matter In: Hard DC Spencer DW (eds) Marine particles: analysis and characterization. Geophysical Monograph 63, American Geophysical Union, Washington, DC

Benner R, Pakulski JD, McCarthy M, Hedges JI, Hatcher PG (1992) Bulk chemical characteristics of dissolved organic matter in the ocean. Science 255:1561-1564

Benner R, Strom M (1993) A critical evaluation of the analytical blank associated with DOC measurements by high temperature catalytical oxidation. Mar Chem 41:1-3

Blackburn HT (1979) Method for measuring rates of $\mathrm{NH}_{4}{ }^{+}$ turnover in anoxic marine sediments, using a ${ }^{15} \mathrm{~N}^{-} \mathrm{NH}_{4}{ }^{+}$ dilution technique. Appl Environ Microbiol 37:760-765

Bronk DA, Gisbert PM (1993) Contrasting patterns of dissolved organic nitrogen release by two size fractions of estuarine plankton during a period of rapid $\mathrm{NH}_{4}{ }^{+}$consumption and $\mathrm{NO}_{2}^{-}$production Mar Ecol Prog Ser 96 $291-299$

Bronk DA, Glibert PM, Ward BB (1994) Nitrogen uptake, dissolved organic nitrogen release, and new production. Science 265:1843-1846

Caperon J, Schell D, Hirota J, Laws E (1979) Ammonium excretion rates in Kaneohe Bay, Hawall, measured by a ${ }^{15} \mathrm{~N}$ isotope dilution technique. Mar Biol 54:33-40

Chin-Leo G, Benner R (1992) Enhanced bacterioplankton production at intermediate salinities in the Mississippi River plume. Mar Ecol Prog Ser 87:87-103

Chróst RJ, Rai H (1993) Ectoenzyme activity and bacterial secondary production in nutrient impoverished and nutrient enriched freshwater mesocosms. Microb Ecol 25 : $131-150$

Coffin RB (1989) Bacterial uptake of dissolved free and combined amino acids in estuarine waters. Limnol Oceanogr $34: 531-542$

Coffin RB, Connolly JP, Harris PS (1994) Availability of dissolved organic carbon to bacterioplankton examined by oxygen utilization. Mar Ecol Prog Ser 101:9-22

Cole JJ, Findlay S, Pace ML (1988) Bacterial production in fresh and saltwater ecosystems: a cross-system overview. Mar Ecol Prog Ser 43:1-10

Cole JJ, Likens GE, Strayer DL (1982) Photosynthetically produced dissolved organic carbon: an important carbon source for planktonic bacteria. Limnol Oceanogr 27: $1080-1090$

Cotner JB, Gardner WS (1993) Heterotrophic bacteral mediation of ammonium and dissolved free amino acid fluxes in the Mississippi River plume. Mar Ecol Prog Ser 93: $75-87$

Fuhrman JA (1990) Dissolved free ammo acid cycling in an estuarine outflow plume. Mar Ecol Prog Ser 66:197-203

Fuhrman JA, Azam F (1982) Thymidine incorporation as a measure of heterotrophic bacterioplankton production in marine surface waters: evaluation and field results. Mar Biol 66:109-120

Gardner WS, Chandler JF, Laird GA, Carrick HJ (1987) Sources and fate of dissolved free amino acids in epilimnetic Lake Michigan water. Limnol Oceanogr 32 $1353-1362$
Gardner WS, Cotner JB Jr, Herche LR (1993) Chromatographic measurement of nitrogen mineralization rates in marine coastal waters with ${ }^{15} \mathrm{~N}$. Mar Ecol Prog Ser 93: $65-73$

Gardner WS, Chandler JF, Larrd GA (1989) Organic mineralization and substrate limitation of bacteria in Lake Michigan. Limnol Oceanogr 34:478-485

Gardner WS, Herche LR, St. John PA, Seitzinger SP (1991) High performance liquid chromatographic determination of ${ }^{15} \mathrm{NH}_{4}:\left[{ }^{14} \mathrm{NH}_{4}+{ }^{15} \mathrm{NH}_{4}\right]$ ion ratios in seawater for isotope dilution experiments. Analyt Chem 63:1838-1843

Gardner WS, St. John PA (1991) High-performance liquid chromatographic method to measure ammonium ion and primary amines in seawater. Analyt Chem 63:537. 510

Glibert PM, Garside C, Fuhrman JA, Roman MR (1991) Timedependent coupling of inorganic and organic nitrogen uptake and regeneration in the plume of the Chesapeake Bay estuary and its regulation by large heterotrophs. Limnol Oceanogr 36:895-909

Goldman JC, Caron DA, Dennett MR (1987) Regulation of growth efficiency and ammonium regeneration in bacteria by substrate C:N ratio. Limnol Oceanogr 32:1239-1252

Hellebust JA (1974) Extracellular products. In: Stewart WDP (ed) Algal physiology and biochemistry. Univ of California Press, Berkeley, p 838-863

Hobbie JE, Daley RJ, Jasper S (1977) Use of Nuclepore filters for rounting hacteria by fluorescence microscopy. Appl Environ Microbiol 33:1225-1228

Keil RG, Kirchman DL (1991) Contribution of dissolved free amino acids and ammonium to the nitrogen requirements of heterotrophic bacterioplankton. Mar Ecol Prog Ser 73:1-10

Keil RG, Kurchman DL (1993) Dissolved combined amino acids: chemical form and utilization by marine bacteria. Limnol Oceanogr 38:1256-1270

Kirchman DL, Keil RG. Wheeler PA (1989) The effect of amino acids on ammonium utilization and regeneration by heterotrophic bactena in the subarctic Pacific. Deep Sea Res 36:1.763-1776

Kirchman DL, Keil RG. Wheeler PA (1990) Carbon limitation of ammonium utilization and regeneration by heterotrophic bacteria in the subarctic Pacific. Limnol Oceanogr 35:1258-1266

Kurchman DL, Suzuki Y, Garsıde C, Ducklow HW (1991) High turnover rates of dissolved organic carbon during a spring phytoplankton bloom. Nature 352:512-614

Lohrenz SE, Dagg ML, Whitledge TE (1990) Enhanced primary production at the plume/oceanic interface of the Mississippi River. Cont Shelf Res 10:639-664

Menzel DW (1974) Primary productivity, dissolved and particulate organic matter, and the sites of oxidation of organic matter. In: Goldberg ED (ed) The sea, Vol 5, Marine chemistry. Wiley, New York, p 659-678

Münster U, Chróst RJ (1990) Origin, composition and microbial utilization of dissolved organic matter. In: Overbeck J, Chróst RJ (eds) Aquatic microbial ecology. Biochemical and molecular approaches. Springer, New York, p 8-46

Nagata T, Kirchman DL (1991) Release of dissolved free and combined amino acids by bacterivorous marine flagellates. Limnol Oceanogr 36:433-443

Pakulski JD, Benner R (1994) Abundance and distribution of carbohydrates in the ocean. Limnol Oceanogr 39:930-940

Palenik B, Morel FMM (1990a) Amino acid utilization by marine phytoplankton: a novel mechanism. Limnol Oceanogr 35:260-269

Palenik B, Morel FMM (1990b) Comparison of cell-surface L-amino acid oxidases from several marine phytoplankton. Mar Ecol Prog Ser 59:195-201 
Rosenstock B, Simon M (1993) Use of dissolved combined and free amino acids by planktonic bacteria in Lake Constance. Limnol Oceanogr 38:1521-1531

Sakugawa H. Handa N (1985) Chemical studies on dissolved carbohydrates in water samples collected from the North Pacific and Bering Sea. Oceanol Acta 8:185-196

Scavia D, Laird GA (1987) Bacterioplankton in Lake Michıgan: dynamics, controls, and significance to carbon flux Limnol Oceanogr 32:1017-1033

Simon M, Rosenstock B (1992) Carbon and nitrogen sources of planktonic bacteria in Lake Constance studied by the composition and isotope dilution of intracellular amino

This article was presented by B. \& E. Sherr (Senior Editorial Advisors), Corvallis, Oregon, USA acids. Limnol Oceanogr 37:1496-1511

Wheeler PA, Kirchman DL (1986) Utilization of inorganic and organic nitrogen by bacteria in marine systems. Limnol Oceanogr 31:998-1009

Wright RT, Hobbie JE (1965) The uptake of organic solutes in lake water Limnol Oceanogr 10:22-28

Zehr JP, Axler RP, Goldman CR (1985) Heterotrophic mineralization of amino acid nitrogen in a subalpine Castle Lake, California. Mar Chem 16:343-350

Zweifel UL, Norrman B, Hagström \& (1993) Consumption of dissolved organic carbon by marine bacterıa and demand for inorganic nutrients. Mar Ecol Prog Ser 101:23-32

Manuscript first received: June 12, 1995

Revised version accepted: October 4, 1995 